\title{
The role of relational marketing on the consumer buying decision of travel agencies
}

Vítor Silva - Instituto Politécnico do Cávado e do Ave (IPCA) - silvavitorhugo@sapo.pt Bruno Sousa, PhD - Instituto Politécnico do Cávado e do Ave (IPCA), CiTUR e UNIAG bsousa@ipca.pt

Márcia Gonçalves, PhD - Instituto Superior de Administração e Gestão (ISAG)- EBS marcia.goncalves@isag.pt

\section{RESUMO}

Este estudo pretende entender como pode ser influenciada a decisão de compra do consumidor no contexto das agências de viagens. $O$ estudo analisa como ocorre a interação relacional entre clientes e empresas do setor, percebendo de que forma as empresas utilizam o marketing relacional como estratégia de mercado e se esse é um fator de influência na tomada de decisão do consumidor. Foram realizadas entrevistas exploratórias com diretores das agências de viagens, com o intuito de compreender a relevância do uso do marketing relacional na criação e manutenção dos clientes das empresas que administram. Os resultados apontam que o uso das relações como fonte de valor nos negócios das agências de viagens é comum e é visto pelas empresas como uma forma de combater a crescente concorrência virtual no mercado, sendo o relacionamento com o cliente visto como um diferencial. e um fator de influência positivo. Do ponto de vista do consumidor, o relacionamento com o agente de viagens é visto como um elemento que aumenta a confiança no produto adquirido, sendo considerado também pelos consumidores como um fator de influência positivo. Foi muito interessante observar a forma como o mercado das agências de viagens sobrevive e como ele se relaciona com os clientes, tornando-se mais competitivo e consequentemente criando valor superior para $\circ$ cliente. Este estudo pretendeu contribuir para 0 marketing de agências de viagens, incentivando o debate sobre o marketing relacional e sua importância no aumento da competitividade do setor. O objetivo do estudo foi analisar os pontos de vista de consumidores e empresas, a fim de promover esse debate e entender os pontos de convergência entre ambos.

Palavras-chave: marketing de relacionamento, agências de viagens, lealdade, satisfação 


\section{ABSTRACT}

Through the characterization of relational marketing, this study intends to understand how it can be influential in the purchase decision of the consumer in the context of travel agencies. The study analyzes how relational interaction occurs between clients and companies in the industry, perceiving how companies use relational marketing as a market strategy, and whether this is an influencing factor in consumer decision making. Exploratory interviews with directors of travel and tourism agencies were carried, with the objective of understanding the relevance of using relational marketing in the creation and maintenance of the clients of the companies they manage. The results point out that the use of relations as a source of value in the business of travel agencies is common and is seen by companies as a way to fight the increasing virtual competition in the market, being the relationship with the client seen as a differentiating and a positive influencing factor. From the point of view of the consumer, the relationship with the travel agent is seen as an element that increases confidence in the product acquired, being considered also by the consumers as a positive influencing factor. This research focused on the analysis of a very modern and pertinent problem, namely the threat of the new business model of the tour operators with their increasing investment in direct sales to the consumer. It was very interesting to observe the way that the market of the travel agencies survives and how it wages on relationships with customers, becoming more competitive and consequently creating superior value for the customer. This study intended to be a contribution to the marketing of travel agencies, encouraging the debate about relational marketing and its importance in increasing the competitiveness of the sector. The aim of the study was to analyze the points of view of consumers and companies in order to foster this debate and to understand the points of convergence between the two parts.

Keywords: relationship marketing, travel agencies, loyalty, satisfaction

\section{INTRODUCTION}

A Marketing has assumed different roles in societies and economies throughout history, and it is interesting to observe the various perspectives it has adopted over time (Sousa \& Simões, 2010; Sousa \& Rodrigues, 2019). Initially seen as a means of leverage production and shipping products, it assumed, at a later stage, a business-only perspective, focused on product and sales (Jarvis, MacKenzie \& Podsakoff, 2003).

With the evolution of consumers, who started to play a more important role in the decisions of the companies and influencing more and more their results, through factors such as their complete and accurate knowledge, 
change of habits, reinforcement of the demand, among others, marketing function had to move towards the consumer, since it did not make sense anymore to neglect one of the main reasons of everyday business (Solomon et al., 2017). In the services sector, this evolution was even more evident. With the tertiarization of the economy, services assumed a more preponderant role in the economic activities of the countries, being a cause of growth and a creator of wealth. In this sense, the personal way that is involved in providing a service brought clients closer to the companies, developing the most relational sense of marketing and making the client a key part of the organization.

The study focuses on the tourism sector, considered by the literature as one of the most promising and challenging sectors of activity worldwide (Ferreira, Sousa \& Gonçalves, 2018). The evolution of the living conditions of the populations of the most developed countries has caused a huge flow of travelers on a global scale, fomenting a deep growth in this sector, generating changes in societies, in companies and in the way people relate to the world. As tourism is a sector of enormous economic importance, with globally growing numbers, it is essential to understand the way in which the supply is distributed and in what way it generates an impact on the daily life of companies and consumers. As in any sector of activity, the tourism sector is composed of several types of actors, from service providers to intermediaries, and also a small number of companies of various types, all of them playing a major role in its development. In this market, travel agencies are one of the most important players in the development of tourism, since the first trip organized by Thomas Cook in 1841, given that the activity of these companies helped the tourism to grow and served as an important intermediary between offer and demand.

According to the technological impact felt in the activity of these companies has triggered some apprehension among their representatives, encouraging their resilience and cunning in the quest for sustainability and competitiveness in an increasingly vulnerable and uncertain market. Threats can turn out to be opportunities and the tourism industry has not refused the evolution, and started to look for its space in the market through the differentiation and the establishment of privileged contacts with the consumer. The globalization of markets promotes an unprecedent competition, making markets unpredictable and diversifying supply, with tourism not being an exception due to its particularities as a market and complexity as an economic sector. According to UNWTO (2011), 51\% of the world's tourist trips are for leisure or vacations, $49 \%$ of which are broken down for various reasons, making clear the complexity of the sector and the difficulty to meet such a differentiated demand. 
According to Umbelino et al. (2012), globalization in the tourism sector goes beyond the diversity of supply and demand, including also the emergence of new agents of supply and new forms of marketing, resulting in differentiated formats of competition, making use of different marketing strategies and innovative communication platforms. Travel agencies, for their part, are experiencing enormous uncertainty. Their daily challenge is to overcome it and to create strategies that make them competitive in a diverse and sometimes unequal market, and proximity to the customer shows up as a strength against the constant threats in a vast and global sector.

This research seeks to understand how marketing strategies, specifically relational marketing, are central to increasing the level of competitiveness of companies in the sector, from the point of view of distribution, differentiation of supply, and essentially in the creation of long-term relationships with customers with a view to their loyalty. On the demand side, the study proposes the understanding of consumer behavior when exposed to this marketing strategy, and how they perceive it and take it in consideration in their choices and in the way they relate to the sector. Based on the mentioned above, the research was built on six specific objectives, through which it will be possible to understand if relational marketing have an impact on the purchasing decisions of travel agent consumers and consequently on their competitiveness. The specific goals of the research are: to carry out a survey of the main marketing strategies carried out by the companies under study; to understand the importance of creating long-term relationships with customers; to understand the relevance of relational marketing in the marketing strategy of tourism companies for customer loyalty; to realize whether proximity and customer relations are a decisive aspect for the commercialization of tourism products; to analyse if the close relationship between customers and companies is a differentiating factor in the competitiveness of the sector, especially in relation to online competition and the tendency of disintermediation; to understand the evolution of the sector and realize the role of the travel agency in the future of the tourism intermediation sector.

Thus, through the study of the relational aspect of marketing, it was intended to capture its importance for the sustainability and competitiveness of companies in the tourism industry, from the point of view of supply and demand, trying to observe if it influences or not consumer decisions. The study was carried out through a careful analysis of the interpretations and characterizations of relational marketing and the way in which service marketing has evolved towards the former, seeking to establish the bridge, from the qualitative point of view, between three essential aspects: the theoretical basis, the opinion of the sector and its consumers. 


\section{LITERATURE REVIEW: RELATIONSHIP MARKETING}

The term "Marketing" arises in the early twentieth century, according to Cobra and Brezzo (2010). This denomination begins to have great relevance in the American universities, where were taught several courses in the areas of sales and distribution, and finally, in the year of 1911, Marketing begins to be taught as a discipline independent of all the others.

According to Kotler (2000), marketing is the art and science for choosing target markets, capturing, maintaining and retaining customers by creating, delivering and communicating a superior value to the customer. For this author, marketing is much more than the simple act of selling a product or a service. In the words of the author, "selling is just the tip of the iceberg". For Marques (2014), from the beginning of the twentieth century until the late 1960s, marketing was directed at the masses, at a time when management focused on production and sales. With the evolution of markets and competition, between the 1960s to the 1980s, the concept of segmented marketing, corresponding to the optics of market orientation and integrated marketing, progressed. According to the author, despite this evolution, up to the end of the 80's the orientation of marketing practices was still much more towards the product and its marketing than to the client. Grven (1997) and Gronross (1989) observe the changes in the business world, initially oriented to production, moving to a more sales-oriented and more recently to the relational aspect.

Relationship marketing is defined by Shani and Chalasani (1992) as an effort to build a network of clients, previously identified, with the objective of maintaining and strengthening this relationship, which is seen as beneficial for both. A new approach to marketing, relationship based, emerged in the 1970s. From the point of view of Percy et al. (2010), this one was portrayed by two main streams of investigation: on the one hand the Scandinavian school and on the other side some western countries. According to Berry and Parasuraman (1993), one of the currents of research is the Nordic School of Service, which studies marketing management from a service perspective. The other stream of research is the Industrial Marketing and Purchasing Group, which heads its investigation from a more industrial perspective (Haikansson 1982).

Grönroos (2007) adds that the research of the Nordic School is more qualitative and conceptual, and there is no room for quantitative studies. Brito (2011) affirms that this school has acknowledged merits in the study of customer loyalty and satisfaction, assuming that, in this area, it is dependent on the quality perceived, determined by two important factors: the expectation of each client and the perception that he has of the service that is rendered to him. According to this, the perceived quality cannot be only 
associated with the perception, on the part of the client, of what the company offers, but also derives from the comparison that the client will make between this perception and the expectations held by him (Sousa \& Vieira, 2018). The Industrial Marketing and Purchasing Group unlike the Nordic School bases its research on quantitative methodologies and case studies. These two schools of thought have a common denominator, being this, according to Gronross (1996), the fact that both orient their research to the relational perspective of marketing.

Kotler and Armstrong (1999) emphasize the importance of maintaining relationships in business, considering that the purpose is to create a long-term link between the parties. The authors affirm, however, that it is important to create value for both companies and customers, thus fostering customer satisfaction and the company's likely success in marketing its products/ services and, consequently, in achieving customer loyalty (Aroeira, Dantas \& Gosling, 2016). For Peppers and Rogers (1997), the market has undergone a great evolution over time, with different and more demanding consumers, forcing organizations to become aware that quality of service is a minimum requirement to be competitive in the market, and it is also visible that relational proximity is a distinguishing factor, and consequently can be a condition for an organization's success. The client, according to Almeida and Pereira (2014), has clearly become the central element in the way companies run their business. They also point out that retention and customer loyalty are an increasingly important priority. From Palmatier (2008) perspective, the starting point for getting to know the customer better is to keep him loyal, which is one of the bases for the success of organizations.

\section{SERVICE MARKETING IN TOURISM CONTEXTS}

Marketing, according to Kotler et al. (2004), is not only a function in the company, but is increasingly becoming a philosophy and a way of structuring the business and its strategy. Tourism is no exception, and according to the authors, customer satisfaction is a central theme in tourism marketing, emphasizing its fundamental benefit to companies (Gosling et al., 2014; Sousa, 2016).

Human needs represent the most basic concept of marketing, from the most primitive to the most elaborate. The absence of a satisfied need transmits a sense of emptiness to the human being, so that the search for the satisfaction of needs is part of the daily life of modern societies (Ferreira et al., 2018). In the case of industrialized countries societies, these needs are mostly satisfied by objects and services. Kotler et al. (2004) describe desire as a human way of expressing needs, influenced by the individual's culture, 
context and geographical location. Thus, the desires evolve according to the individual's exposure to a certain quantity and quality of objects and services, being something that the managers of the companies work in an influential way in order to obtain results. Also the market demand is influenced by needs and desires, and can be defined as a mix between unlimited desires and limited resources. Consumers typically look for products that target their desires, which in turn, reflects on demand. The understanding of these characteristics, needs, desires and demand, usually define the success or failure of the company's marketing policy. When a client acquires a product or a service he is looking for value, which creates in the client the satisfaction of the consumption of the product/experience (de Freitas Coelho, Meira \& de Sevilha Gosling, 2018). As said before, this satisfaction will only be obtained through the correspondence between the expectations that the consumer had before the consumption and the perceived quality of the product or the service and its ability to meet the clients needs. If this correspondence is not verified, there are two other possible scenarios: or the customer sees his expectations defrauded, which will lead to discontent ans insatisfaction, or the customer is surprised and sees his expectations exceeded, thus increasing his degree of satisfaction. That's why it is essential that companies at least match and deliver what they set out to offer when a particular product or service is marketed, or if possible, add value to what was expected, so that the customer becomes enchanted and, consequently, loyal (Bigné et al., 2005). The consumer's expectations on the product/service that will be consumed is always based on previous experiences or opinions obtained from various sources, and it is essential that companies generate the best possible opinion in the provision of their services so that the customer is tempted to return and to recommend, which usually results in repeated purchases and capture of new customers. A company oriented towards the relationship with their customer will achieve more easily the best satisfaction for them, generating profitability for the company (Buhalis \& Law, 2008). Thus, the creation of value and customer satisfaction are, according to the authors, related to the quality of the product/service provided and the absence of defects, in a more restricted sense of quality. The company's quality policy, well executed, will convey to the customer the confidence desired by the marketing team.

Other important aspect is the interchange between transactions and relations, this latter emphasized by Kotler et al. (2004) as the heart of the matter, since transactions and exchanges are the beginning of the business relationship between the company and the client. In short, relationships arise through transactions and exchanges, with transactional marketing increasingly tending towards relational marketing, since marketers are betting on creating relationships with all stakeholders in the business in order to 
generate value for the company in a global perspective. In this sense, the maximization of relations is a paradigm shift in marketing, since the strictly economic sense of marketing is giving room to a more relational policy. The marketing concept, based on the interaction between the various moments and actors in the business, is portrayed by the picture below by Kotler et al. (2004), defining marketing as a social process.

Figure 1: Marketing concept

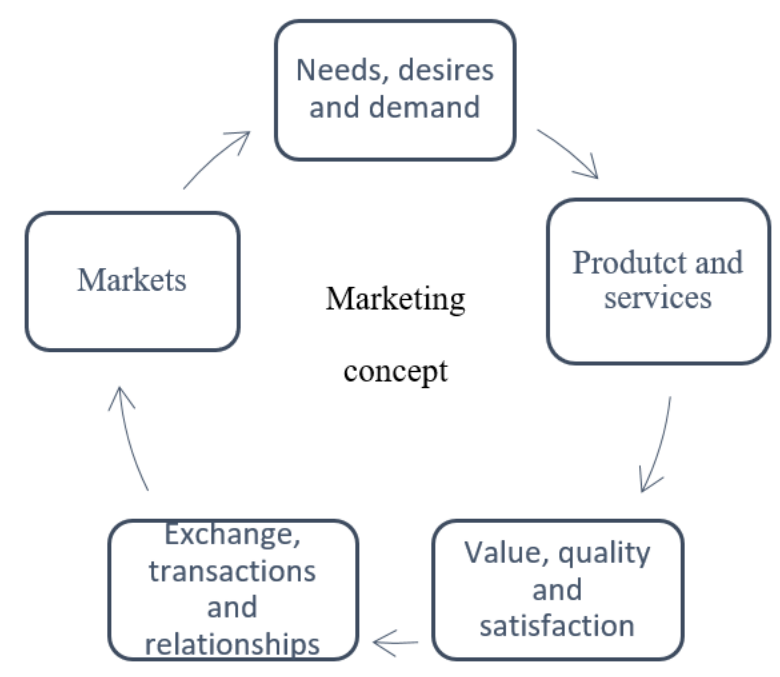

Source: Adapted from Kotler et al. (2004)

\section{TRAVEL AGENCIES AND THE NEW INDUSTRY PARADIGM}

According to Abranja et al. (2012), the first organized collective trip was made by Thomas Cook in the year 1841, and to this day is known as the first act of tourism intermediation. Nowadays, according to the author, travel agents have been the main intermediaries in the tourism sector, contributing significantly to the evolution and development of destinations and tourism companies, acting as a bridge between consumer demand and the operators offer. The definition of the role of the travel agent, individual or collective, is characterized by Mclntosh et al. (2002) as an intermediary acting on behalf of one or more organizations selling their services to clients in exchange for a commission for the brokerage service.

Travel agencies are, according to Muñoz Oñate (1994), retail companies inserted in the market of tourism distribution, having as their main characteristic the connection to the tourist producers, thus supplying the requests of the clients. In turn, Albert (1990) summarizes the activity of travel agencies in three main functions, as the mediating, advisory and production 
function. These functions are well represented in the next picture, adapted from Abranja et. al. (2012):

Figure 2: Characterization of travel agency activity

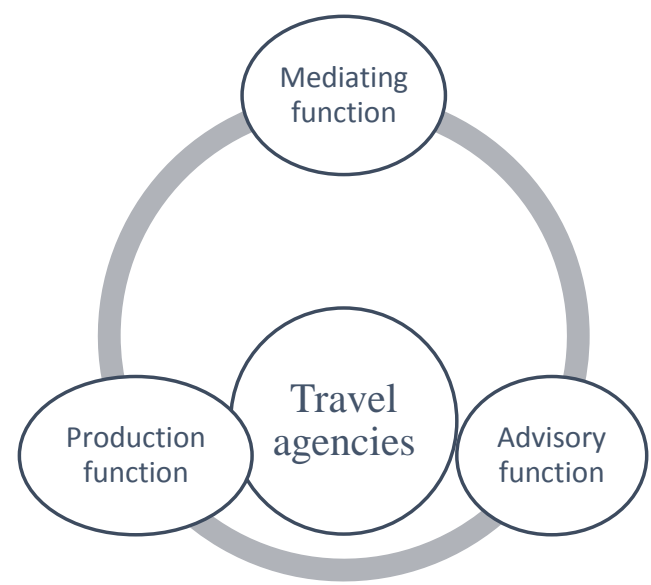

Source: Adapted from Abranja et al. (2012)

The panorama of globalization is transversal to all the economic sectors, being the economic world active and competitive. Given this scenario, Trible (2003) states that tourism companies must adapt to this new economic setup, stressing that tourism market development is characterized by 4D's: Difficult, Devastating, Dynamic and Differentiating, and emphasizing that only resilient, innovative and energetic companies will be able to survive in this dynamic market. According to Poon (2006), tourism is abandoning the old format, based on mass tourism, and rigid in its conception, embracing a more flexible, more segmented format, being more and more moldable to the tourist and its typologies. Cunha (2001) argues that the globalization of markets is a stimulus for companies to associate with each other and form alliances that support the tourism market, which is a sensitive one and is dependent on several political, social, climatic factors, among others. These alliances would contribute to effectively combating these unpredictabilities, ensuring a stable flow of consumers and tourists, enabling the companies to be better organized. From the perspective of Kotler et al. (2005), faced with these constraints in the tourism market, the policy of partnerships, sharing and synergistic action, may be the difference between an efficient and competitive company and one in a constant struggle for survival.

According to Warnecke (1993), companies must be agile in a fast changing context, with flexibility being an organizational paradigm shift, based on three key characteristics: the dynamics of change, the rapid response and the notion of total quality. Porter (2001) observes a great 
revolution in the way of doing business in the last decades, which have contributed a lot to the competitive pressure generated by the new technologies and the phenomenon of globalization.

According to Buhalis and Ujma (2006), travel agencies are inserted in a market with a severe competitiveness, and this scenario presents a wide range of threats to the tourism intermediation activity, but also presents new opportunities where only companies that can add value to the industry can overcome this new business paradigm. The emergence of new platforms, blogs, search engines, opinion sites, influencers and other types of media affect in a significant way the shape and posture of traditional travel agents (Buhalis, 2006). Given this reality, as well as the evolution of the sector in terms of technology and organization, UNWTO (2001) warns that travel agents should specialize and offer their customers more value by becoming a partner and not a simple intermediary. Travel agencies should act as travel consultants, using their experience and knowledge in the product they commercialize, being this an important strategy for these companies to maintain themselves as important parts of the tourism market.

According to Gomis and Borja (2006), the travel agent must undergo changes at various levels, from commission agent to consultant, expanding its value and supply chain, increasing its quality and productivity. It should also create new sources of revenue and have a permanent knowledge of the trends, bridging the desires of its customers, being able to implement and use tools such as Consumer Relationship Management (CRM), highly useful in the segmentation of the market and in the relationship with its customers, strengthening ties and becoming strongly competitive before the market, privileging the differentiation to the detriment of the massification. According to Buhalis and Ujma (2006), the new travel agent should not consider the internet a threat or unfair competition, facing it as an essential tool in its activity, becoming a user of the most sophisticated tools and functionalities.

From Buhalis perspective (2006), the travel agency must take advantage of the aspect that seems to be the great tendency at the present, which has to do with the new profile of the client, since he travels more and more and considers travel and tourism an essential part of his life. According to Marques (2014), the future of companies is no longer exclusively in the hands of their managers, since the connected market allows the consumer to quickly analyse and access alternatives, making consumer loyalty a more volatile term. From the perspective of consumers, market research allows them to make better decisions, based on the opinions and texperiences reports they obtain, which reflects and reinforces the power of the customers in the future of the companies. In spite of all the revolution observed in the market, motivated by the development of new technologies, 
according to Marques (2014) not everything has changed, being important to remember that we are in an era of convergence between the technological and the traditional, both being important, since the client is widely informed but seeks experience and proximity, and goes after options that are accurate and that add value. That's why the proximity of the companies with their clients turns to be so important, enabling companie's knowledge about their clients needs, expectations and desires and the consequent understanding of their thoughts and behaviours.

According to Marques (2014), evolution cannot and should not be stopped, and it is important for companies to adapt to the reality they are facing, giving importance and priority to marketing and customer loyalty strategies and convergence between online and offline marketing, associated with relational marketing. According to the author, loyalty may reduce the uncertainty and the various costs related to managing customer relationships, as can be seen in the picture that follows.

Figure3: Reasons for customer loyalty

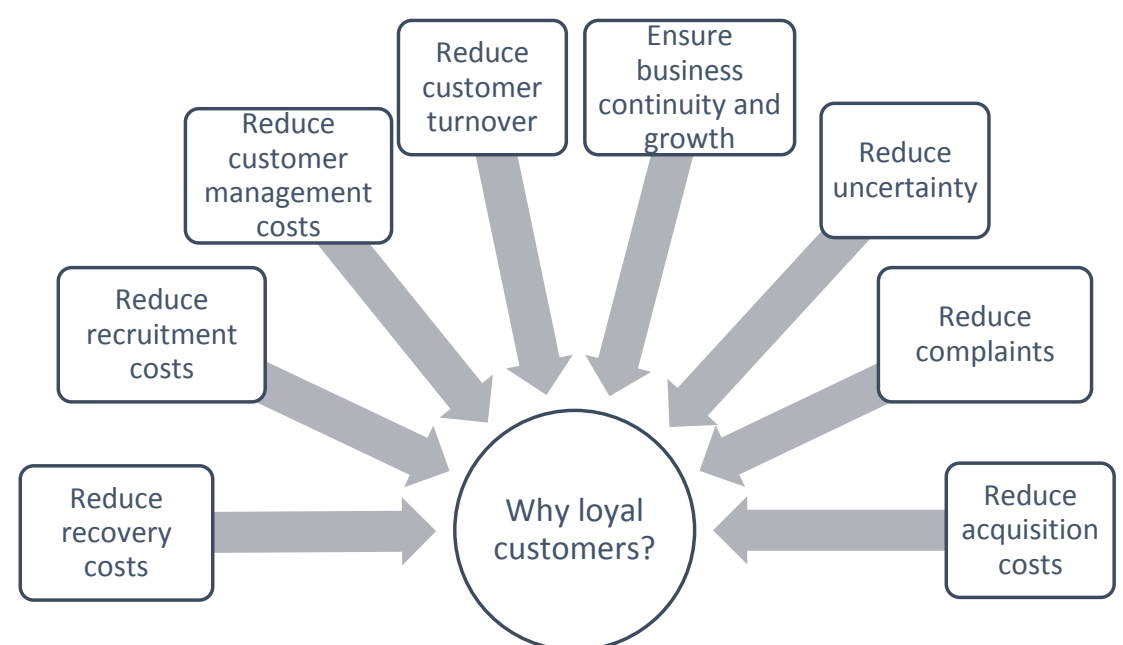

Source: Adapted from Marques (2014)

\section{METHODOLOGY}

The development of this research was based on a qualitative methodology, with the goal of studying and perceiving a certain phenomenon. According to Malhotra and Birks (2006), the qualitative research allows the investigator to know the reasons that are in the base of a certain phenomenon, allowing the perception of its underlying motivations. According to Wahyuni (2012) the elaboration of the research is the link between the methodology and an appropriate set of methods. In sequence, 
Malhotra and Birks (2006) suggest that in this set of appropriate methods are detailed the procedures necessary to obtain the desired information and thus achieve the proposed research objectives. The authors note that in qualitative research a small number of non-representative cases are used, the collection of data is not structured and its treatment is not statistical. The development of this research had as its starting point the goals that were previously presented. The data was obtained through two different methods and moments: from the point of view of the companies using semi-structured interviews to directors of travel agencies, and, from the point of view of the consumer, using a focus group with clients of travel agencies, allowing the analysis and confrontation of both points of view.

According to Wahyuni (2012), the collection of data from multiple sources enables the researcher to cross-respond to different questions from the same reality under analysis. The interview guide were previously elaborated, obeying a certain structure, allowing the emphasis on the subject to be analysed and at the same time giving the interviewee the flexibility and freedom for reasoning, allowing him to be spontaneous in his answers and faithful to his ideas.This way, a semi-structured interview was used, based on Wahyuni recommendations (2012), and applied to travel agency directors. In order to gain awareness about the opinion of the consumers of the travel agencies, it was performed a focus group, being this the second moment of collection of data, that was essential for the correlation and comparison of the data obtained in the investigation. According to Morgan (1997), the focus group is a qualitative research technique that aims to collect information based on the interaction between a certain number of participants. Following the recommendations of Barbour and Kitzinger (1999), the group was organized based on fundamental criteria such as: resources needed; definition of participants; profile of participants; selection process and duration time.

Ten consumers of travel agents were present in the focus group, debating the topics previously presented, for approximately two hours, following the recommendations of Krueger (1998) and Morgan (1988). The debate proceeded, following the recommendations of Veiga and Gondim (2001), in a fluid and natural way, ending at the moment when it was noticeable that the presented ideas would not add essential points for the goals of the investigation. According to Carlini-Coltrini (1996), the honesty and depth with which the topics are exposed in the discussion are essential for the objectives of the research, and the lack of connection between the participants is important as it allows them to have a greater freedom of opinion. This way, the selection of the participants was based on a choice that would serve the research objectives without compromising its reliability. 
The guides used for the semi-structured interviews and for the focus groups can be found below:

Guide for semi-structured interview to directors of travel agencies

The present interview is aimed to directors of travel and tourism agencies, or their representatives in order to obtain the business perspective of the importance of relational marketing for the business

1- What are the main concerns of the company at the marketing level?

2 - Do you consider that proximity to the customer is an important aspect in the creation of a relationship of trust between the agency and the client?

3. Do you think that closer ties with customers is a way of getting around the constant threats and changes in the tourism market?

4- Do you feel that a close relationship with the customers facilitates the sale of the products marketed by the agency?

5 - Today it is common practice for suppliers of tourism services to bet on the direct sale of their products, using online platforms that are increasingly intuitive and user-friendly, overcoming the mediation of the agencies. Do you think that the proximity and trust that the travel agent can convey to the customer is a key point to fight this direct sale?

6- The world has globalized itself and the dissemination and promotion of information and products is often a click away. Thus, do you think the socalled "word of mouth" advertising is still important? Do you consider that this factor leads you to believe that a satisfied customer is synonymous with new customers?

7- In your view, what do you think are the advantages of investing in a long-term relationship with your customers?

8- In your opinion what are the main challenges that the agency faces in terms of customer loyalty? customer?

9- To what extent can we say that a satisfied customer is a loyal

10 - Do you feel that the close relationship with the client allows the company to obtain important feedback that leads to the improvement of the service provided?

11- Can the Internet change the agent / customer relationship? In a positive or negative way? 
12. When we talk about Relational Marketing, do you think it is strictly personal or that it can be developed using online communication / contact?

13- Does the company use web marketing to promote itself to its customers?

14- How do you see the future of travel agencies and tourism?

15- In your opinion, what will be the main differences between the role of the travel agency today and its role in the future?

Guide for focus group with clients of travel agencies

In a global and competitive world, travel and tourism agencies are betting more than ever in being close to the customer and in providing an increasingly personalized service.

Marketing has, as literature points out, a relational essence. All marketing definitions emphasize the proximity of the company to its public, leading it to create stable ties with them.

The purpose of this focus group is to understand the characteristics of travel and tourism consumers, their degree of loyalty to the companies and the extent to which they are influenced by agency marketing policies, namely relational marketing.

The debate between the participants of the Focus Group should follow the following points:

- Determining factors in the purchase;

- Influence of Marketing in the fixation of the consumer to a brand / company;

- Realize what the consumer understands as relational marketing;

- Understand the influence that the travel agent has nowadays on the purchase decision;

- Existence, or not, of a clear preference for a company where there is a bond between the consumer and the company or any representative of the company;

- Perception of the point where the trust relationship ceases to be fundamental for the purchase decision;

- In a market increasingly dominated by technologies, where the role of intermediation is many times outweighed by technological means, to what extent is the travel agent important and if its role is irreplaceable; 
- Importance of Relationship with company and / or company representative in the management and resolution of conflicts;

- Identify the relevant advantages and disadvantages that consumers see in the relationship with a particular company and / or agent;

- The role of the travel agency in the present and in the future;

- Realize whether relational marketing, from the point of view of the consumer, is something strictly personal or gained a new dimension through remote contacts: newsletters, phone contacts, social networks, etc.

\section{ANALYSIS AND DISCUSSION OF RESULTS}

The sample description is presented in the tables below, with some data related to the companies and their respective representatives who were interviewed and also related to the participants of the focus group:

\begin{tabular}{|c|c|c|}
\hline Company & City & Interviewee's position \\
\hline 1 & Barcelos & CEO \\
\hline 2 & Viana do Castelo & $\begin{array}{c}\text { Commercial } \\
\text { Representative }\end{array}$ \\
\hline 3 & Coimbra & Regional Director \\
\hline 4 & Barcelos & CEO \\
\hline 5 & $\begin{array}{c}\text { Vila Nova de } \\
\text { Famalicão }\end{array}$ & $\begin{array}{c}\text { Maketing and } \\
\text { commercial director }\end{array}$ \\
\hline \multicolumn{2}{|c|}{ Table 1. Company profiles of the directors/representatives interviewed } \\
\hline
\end{tabular}

\begin{tabular}{|c|c|c|c|c|}
\hline Participant & Gender & Age & Education & Occupation \\
\hline 1 & $F$ & 28 & Master Degree & $\begin{array}{c}\text { Administrative } \\
\text { technician }\end{array}$ \\
\hline 2 & $M$ & 35 & $9^{\text {th }}$ grade & Textile Worker \\
\hline 3 & $M$ & 34 & $\begin{array}{l}\text { High school }\left(12^{\text {th }}\right. \\
\text { grade) }\end{array}$ & Policeman \\
\hline 4 & $\mathrm{M}$ & 32 & Master Degree & Designer \\
\hline 5 & $\mathrm{~F}$ & 30 & Bachelor Degree & Education assistant \\
\hline 6 & M & 28 & $\begin{array}{l}\text { Higher Military } \\
\text { Training }\end{array}$ & Army official \\
\hline 7 & $M$ & 45 & $9^{\text {th }}$ degree & Driver \\
\hline 8 & $M$ & 29 & Master Degree & Designer \\
\hline
\end{tabular}

Hakansson and Snehota (2000) argue that relationships are knowledge clashes, and this idea is important to keep as a starting point for the analysis of the data obtained from the representatives of the companies under study and also from the consumers and frequent clients of travel agencies. The 
information gathered during the interviews with the managers of the companies contributed to emphasize the idea that the organizations exist because of the people who intervene in the various moments inherent to a business, from the suppliers to the clients, throughout the specialization of the professionals who represent companies to their clients. From this point of view, consumers expect to be in contact with an experienced and knowledgeable professional in the market and in the products they market, valuing their skills which are determinant for the options they take. Companies are well aware that competition in today's market depends on the added value they bring to consumers, since differentiation lies essentially in the quality and the way they deal with the situations they face in their daily operations. The representatives of the companies under study believe that their clients value the company for the services it provides, but much more for the way it relates to them, stating on several occasions that the customer is the focus of the company, for whom it directs the skills. The travel agents interviewed in the scope of this research claim that customization is the opportunity they have to differentiate themselves from other competitors, using relational strategies to obtain the maximum knowledge of their target audience, be more incisive in approaching the customers and, consequently, more assertive in the suggestions.

Obviously, these customer relation policies do not go unnoticed by consumers and, in the focus group, it was possible to verify that one of the determining factors pointed out by the consumers is the feeling of being part of the companies, explaining on several occasions that their travel agent is a partner. The relationship between the parts of the business is described by both as a sharing of experiences and knowledge, where the opinion of each is taken into account, this being a factor of satisfaction, primarily for the consumers, who affirm that it is a relevant fact, even when travel is not what they expected.

Regarding the marketing policies of the companies, and obviously taking into account the different typologies and characteristics of their own, the interviewees were conclusive when affirming that the focus is the customer and his satisfaction, with the objective of promoting their services in a customized way to each target. Although they all market similar products with common suppliers but with differentiated bets in each of the companies, it was interesting to note that each interviewee pointed to a market or a typical customer as a determining factor in their commercial efforts, perhaps because of the location or typology of more frequent customers. In this point of view, consumers are more convergent about the reasons why they resort their "preference" agencies, stating that it is not so much about marketing as it is about the positive experiences in a broad sense, which include conflict management, and the confidence they place in their travel agent. The 
decision to resort to a qualified professional, such as the travel agent, is, according to the opinion of the consumers, a way of seeking trust and a search for the comfort that the presumed experience provides to them. They claim that sometimes their ideas about a given destiny or option are modified by the influence of the agents' advices, which in general are valid and assertive. The relational aspect is important, according to these, and even essential in some typologies of trips with more specific characteristics and of greater complexity of organization.

Marketing is seen by consumers in the focus group as something that sometimes is excessive, feeling overwhelmed by the commercial pressure they are subjected to by companies. From this point of view, participants believe that the best marketing is satisfaction with the services provided and the way they are treated by the companies, emphasizing that these reasons often exceed the economic factors that are most unfavorable, because of the understanding they feel. Following this idea, participants consider themselves as "bridges" of the marketing of the companies, affirming that several times they recommend the services to others due to the satisfaction they felt. They consider that the best marketing that these companies can hold is the one based on the good experiences that the company and its collaborators have provided them with, emphasizing, this way, the value that they attribute to the relationship marketing. In turn, agents recognise the importance that must be placed on the relationship they maintain with the clients, because they are aware of the difference that this relationship can mean in the management of positive and negative situations, as well as the significance that the recommendation of their companies to new clients can have in the increase of the competitiveness that they ambition in the market.

Through the analysis of the opinions about the marketing policies of the companies, it was noticed that these are directed to their targets, being determined by the awareness of the need for specialization on more specific audiences, with characteristics that reveal an opportunity to explore. It is clear to all the interviwees that loyalty is one of the main goals of companies, because it allows a better knowledge of the client and its characteristics, which means an added value to the achievement of good businesses. The agents are aware of the vulnerable market in which they operate, affirming several times that it is not easy, in the current context, to retain and consider a client as a guarantee, since the latter, according to its own, is permeable and receptive to the diverse offer that the market has and, even when there is a relationship with a particular company and the customer considers himself faithful, agents perceive that there are conditions that both parties cannot control, being the economic aspect one of the main reasons for losing customers. 
In this topic, in the focus group, although participants considered themselves faithful to "their" agencies, they admitted that they look for information in the market, namely on the Internet, and that sometimes they use this information as a form of pressure, in order to obtain better negotiations. Consumers consciously and clearly observe the evolution that the travel and tourism market has passed through, realizing that in a few years the way to approach this theme has shifted from a standardized, segmented offer to a dispersed offer, coming from various sources, accessible through a lot of different means. It is mentioned throughout the discussion that the information is at a distance of a simple click and that today there is no need to acquire something without this precedent act of information search. In this way, they admit that the pressure has increased on the supply side and that the competition is huge. Participants also admit that for certain trips, which they consider to be simpler, they resort to online shopping where prices are more appealing. From this point of view, consumers do not think that loyalty must necessarily be synonymous of exclusivity, considering that loyalty is a type of relationship with an entity that gives them security and confidence that others do not match. Consumers feel that the advantages of loyalty lie in the long-term relationship they maintain with entities, believing that these are part of their choices because of the knowledge and experience that they have with these companies. In the course of the discussion, consumers said that the agencies where they are perceived as loyal customers are considered a "safe haven" in a market with a lot of supply, functioning as the most guaranteed choice, where they believe they can trust. They clarify that despite the diversification of supply, there are more and more dangers, such as false offers, dubious conditions, which sometimes lack legality, confidence and even safety, and therefore reinforce the comfort they feel when advised by a person experienced in the matter and with evidence of professional integrity, putting in evidence the relational relevance that the question rises.

Regarding the primary issue of this research, the impact of relational marketing on the consumer buying decision of travel agents, both views are conclusive in that it is an influential factor, considering that the relationships we maintain with others are always influential and can generate opportunities, with success or failure. From the point of view of companies, relational turns out to be an opportunity to fight the virtual supply and the tendency of disintermediation of the sector, serving as a differentiating factor, since, as they say, there are factors in a particular relationship that are not substitutable: the personal contact and resulting costumization, that allows companies to save the consumer from standardization, could work as a unique and unparalleled competitive factor. This point of view is shared by consumers, stating that the factors they value in a personal relationship are not interchangeable and in several situations the opinion of the agent in 
which they place confidence by their experience and wisdom in the matters that lead them to the travel agency, determines the completion of the business. The organization of a trip, according to consumers, has a diffuse idea as a starting point, in most situations, only being achievable and possible to carry out after a dialogue and the sharing of opinions with the agent. The opinion about the influence of the relational aspect in the purchase decision is shared by both perspectives in analysis, being seen by the companies as an opportunity and a distinguishing factor of competitiveness, and by consumers as a comfort and security aspect, revealing trust as determinant in the relational connection with a certain company.

In summary, despite the fact that the travel agency sector is in great change, essentially related to the technological impact it has suffered since some years ago, both study perspectives seem to find space for these companies to operate and obtain excellent results, revealing that difficulties can and should be transformed into opportunities and that the technological impact cannot and must not be contradicted but, in the opposite direction, there must be an adaptation in order for companies to operate with the same capacities in such a vast market. Consumers believe that coexistence between online and offline is truly possible, and one is not a substitute for the other, they must coexist and act on the lines that are intended for them, because, in their opinion, the market requires solutions and these are not exhausted in one type of supply. On the companies side, corporate representatives are more skeptical in their market analysis, and confess themselves a bit uncomfortable with what they define as disintermediation and deregulation of the sector, even though they consider that the sector has never been so regulated by competent authorities. In this respect, they consider that companies operating in a virtual world circumvent such regulations and operate in the same market under more favorable conditions. Despite these factors, respondents are optimistic and show resilience and ability to overcome difficulties and threats, focusing on specialization and differentiation as primary aspects, reaching out to an audience that seeks differentiation and through personalization, thus moving away from standardized consumers.

\section{CONCLUSIONS AND NEXT STEPS}

Having reached this stage, it is important to reflect on all the results for which the study points out, focusing on the evolution that the business world must embrace to follow the increasingly informed and evolved consumers. Customers are more enlightened, taking advantage of the ease that the 
democratization of the use of technologies allows in obtaining information, pressing companies to change and to accept their ideas. In this way, several authors refers to the client as a key aspect in the decisions of the current organizations, and as a factor that should be part of the main policies of action they take. The negotiation power that consumers have nowadays, which is followed by their pressure to lower prices or offer more advantages, triggers a state of uncomfortable vulnerability in the companies and in their decision makers.

It is true that the companies, under which the study falls, feel this instability deriving from two essential factors: first by the instability of the clients, for the above mentioned reasons, and second by the technology revolution that the sector has undergone in the last years that has caused a growth of new competitors that turn the market more unpredictable.

Nevertheless, travel agents seek to ensure their role in the tourist market, pursuing a better knowledge of their customer and trying to be closer to him, making him part of their activity and a real partner, and not only a simple customer or someone with limited importance. It is particularly interesting to note that, at a time when huge amounts are invested in competent information systems where everything is recorded, the customer is still a so unpredictable target. The loyalty of the customer to the company is no longer a reliable term, being something that needs too many conditions to be verified. When it comes to a service, as it is an experience of the customer and has an not measurable character, it assumes different characteristics for each consumer. Thus, the perception of quality degree of the service will be different from customer to customer, reinforcing the idea that personalization of the service can be a mean to increase the degree of satisfaction of the ones who will enjoy it.

Relational marketing arises through the needs brought by the evolution of services, since its diversified characteristic forces companies to know to whom they are recommending or selling a particular service, which implies a prior knowledge of the customer. The relational marketing policy requires value creation for both parties involved in the business, and this feature has been emphasized and affirmed, several times, in the various moments that led to the production of this study: literature, interviews and the focus group. Relationship marketing is an influential factor in the decisions of both sides of the business; if, on one hand, from the perspective of companies, it requires a deep knowledge of its clients and changes the way they present themselves to the market, being more incisive in their policies, adapting and targeting their offer to the different types of customers they have, with a view to differentiation and loyalty, on the other hand, from the point of view of consumers, influences the purchase decision, since it changes the way they 
buy, because although they consider themselves informed, they admit that they change their options on a number of occasions according to a recommendation of those they consider to be experienced and wise in the area, and at the same time, in whom they trust and know that they can appeal in the event that something fails.

It is true that the future is unpredictable and difficult to anticipate, but companies must be aware that the future is prepared in the present, and adapting supply to demand is a way of monitoring what the market misses. Opportunities are the result of innovations, and through relationships all stakeholders can identify what is reserved in a next step, knowing that there will always be threats to what is the known reality, but the overcome of these is synonymous with the sougth competitiveness. Future studies may allow researchers to develop studies of a quantitative nature, namely by empirically testing some conceptual models and verifying causal relationships between variables such as affectivity, commitment, satisfaction, and loyalty. In future research, we intent to show shows how these valid questions can be answered by introducing causal modelling and discussing one approach to it, structural equation modelling (SEM), which is a rigorous technique for building and testing such models (Gosling \& Gonçalves, 2003). It is an advanced statistical methodology that delivers models and results that are easy to understand and employ. We intent to confirm that a causal relationship exists (i.e. measurement over time should confirm that change in one variable precedes change in the other; a controlled experiment is required that changes a single variable; the direction of causality must be correctly specified; the relationship must not disappear when common causes of both are removed and the causal effect 'makes sense' in domain knowledge) (Sousa \& Simões, 2010).

The study presents as main limitations the small number of interviewed companies, despite the large number of contacts established, due to the fact that many companies didn't agree to participate in the study. Other limitation that can be pointed out is the fact of being performed a single focus group, that was mainly due to logistical difficulties, related to the existence of a neutral space available to hold the meeting and the scheduling in order to gather the availability of all participants. Also, focus group participants were all in a very close age group, and it might be interesting to include people from other age groups in order to make the discussion richer.In future works, it is intended to develop the study using quantitative methodology, namely finding possible causal relations between some relational marketing variables (e.g. perceived quality, expectations, trust, commitment, satisfaction and loyalty). It will be our purpose, in future investigations, to run questionnaires to consumers of travel agencies in order to understand the impact and the relationship between these variables, thus 
making the study complementary to the one developed here by the researchers.

\section{REFERENCES}

Abranja, N., Alcântara, A., Braga, C., Marques, A., \& Nunes, R. (2012). Gestão de agências de viagens e turismo. Lisboa: Lidel.

Almeida, M. D. R., \& Pereira, J. M. (2014). Marketing de serviços. Edições Sílabo.

Aroeira, T., Dantas, A. C., \& Gosling, M. D. S. (2016). Experiência turística memorável, percepção cognitiva, reputação e lealdade ao destino: um modelo empírico. Turismo: Visão e Ação, 18(3), 584-610.

Barbour, R. S., \& Kitzinger, J. E. (1999). Developing focus group research: Politics, theory and practice.

Berry, L. L., \& Parasuraman, A. B. R. A. H. A. M. (1993). Building a new academic field-The case of services marketing. Journal of retailing, $69(1), 13-$ 60.

Bigné, J.; Andreu, L. \& Gnoth, J. (2005). The theme park experience: An analysis of pleasure, arousal and satisfaction. Tourism Management, 26, 833844.

Brezzo, R., \& Cobra, M. (2010). O novo marketing. Rio de Janeiro: Elsevier.

Brito, C. (2011). Marketing relacional: das origens às actuais escolas de pensamento.

Buhalis, D., \& Costa, C. (Eds.). (2006). Tourism management dynamics: trends, management and tools. Routledge.

Buhalis, D., \& Ujma, D. (2006). Intermediaries: travel agencies and tour operators. In Tourism Business Frontiers (pp. 171-180).

Carlini-Cotrim, B. (1996). Potencialidades da técnica qualitativa grupo focal em investigações sobre abuso de substâncias. Revista de Saúde Pública, 30, 285-293.

Cunha, L. (2001). Introdução ao turismo. $1^{a}$. Lisboa: Verbo.

de Freitas Coelho, M., Meira, K. C. O., \& de Sevilha Gosling, M. (2018). Experiências memoráveis de viagens de casais. Revista Brasileira de Pesquisa em Turismo, 12(1), 157-179.

Ferreira, J., Sousa, B. M., \& Gonçalves, F. (2018). Encouraging the subsistence artisan entrepreneurship in handicraft and creative contexts. Journal of 
Enterprising Communities: People and Places in the Global Economy. https://doi.org/10.1108/JEC-09-2018-0068

Gomis, J. M., \& de Borja, L. (2006). Modelos de innomediación en el marco de un nuevo paradigma de la intermediación turística. VI CongresoNacional "Turismo y Tecnologías de la Información y las Comunicaciones, 213-226.

Gosling, M., \& Gonçalves, C. A. (2003). Modelagem por Equações Estruturais: conceitos e aplicações. Revista de Administração FACES Journal, 2(2).

Gosling, M., Coelho, M., \& Resende, M.P. D. L. (2014). Qualidade percebida e intenções comportamentais de visitantes em museus: uma proposta de modelo. Turismo-Visão e Ação, 16(3), 656.

Grönroos, C. (1989). Defining marketing: a market-oriented approach. European journal of marketing, 23(1), 52-60.

Grönroos, C. (1996). Relationship marketing logic. Asia-Australia Marketing Journal, 4(1), 7-18.

Grönroos, C. (1996). Relationship marketing: strategic and tactical implications. Management decision, 34(3), 5-14.

Gronroos, C. (2007). Service management and marketing: Customer management in service competition (Vol. 3). Chichester: Wiley.

Gruen, T. W. (1997). Relationship marketing: the route to marketing efficiency and effectiveness. Business Horizons, 40(6), 32-38.

Hakansson, H. (1982). International Marketing and Purchasing of Industrial Goods. IMP Project Group.

Hakansson, M., \& Snehota, I. J. (2000). The IMP Perspective. Assets and Liabilities of Business Relationships. Handbook of Relationship Marketing. JN Sheth, A Parvatiyar.

Jarvis, C. B., MacKenzie, S. B., \& Podsakoff, P. M. (2003). A critical review of construct indicators and measurement model misspecification in marketing and consumer research. Journal of consumer research, 30(2), 199-218.

Kotler P. (2000). Administração e Marketing: a edição do novo milénio. 10a ed. São Paulo: Prentice Hall.

Kotler P. Armstrong G (1999). Principles of marketing 8th Edition. New Jersey: Prentice hall, Upper Saddle River.

Kotler P., Bowen J., Makens J., Moreno R., Paz R. (2004). Marketing para Turismo. $3^{a}$ ed. Madrid: Prentice Hall. 
Kotler, P., Bowen, J. e Makens, J. (2005), Marketing for Hospitality and Tourism, DInternal. Distribuidora Internacional do livro Lda.

Krueger, R. A. (1988). Focus groups: A practical guide for applied research.

Malhotra, N. K., \& Birks, D. F. (2006). Marketing research: an applied approach Marques A. (2014). Marketing Relacional. Como transformar a fidelização dos clientes numa vantagem competitiva ( $2^{a}$ Ed.). Lisboa: Edições Sílabo.

Mclntosh, R. W., Goeldner, C. R. e Ritchie, J. R. B. (2002). Turismo - Princípios, Práticas e Filosofias. $8^{a}$ edição. São Paulo: Bookman

Morgan, D. L. (1988). Focus groups as qualitative research. In Qualitative Research Methods (No. 16). Sage Publications.

Morgan, D. L. (1997). Focus Group as Qualitative Research.: Sage. Thousand Oaks.

Morgan, D., \& Krueger, R. A. (1998). The Focus Group Guidebook (Vol. 1). SAGE.

Muñoz Oñate, F. (1994). Marketing Turístico. Madrid: Editorial Centro de Estudios ramón Areces, S.A.

Palmatier, R. W. (2008). Relationship Marketing. Cambridge Massachusetts: Marketing Science Institute.

Peppers, D., \& Rogers, M. (1997). Empresa 1: 1: instrumentos para competir na era da interatividade. Rio de Janeiro: Campus.

Percy W. Visvanathan N. Watson C., (2010). Relationship marketing: Strategic and tactical challenges for SMEs. African Journal of Business Management Vol 4(13), p. 2596-2603.

Poon, A. (2006), Tourism, Technology and Competitive Strategies, Cabi.

Shani, D., \& Chalasani, S. (1992). Exploiting niches using relationship marketing. Journal of consumer marketing, 9(3), 33-42.

Solomon, M. R., White, K., Dahl, D. W., Zaichkowsky, J. L., \& Polegato, R. (2017). Consumer behavior: Buying, having, and being. Boston, MA, USA:: Pearson.

Sousa, B., \& Rodrigues, S. (2019). THE ROLE OF PERSONAL BRAND ON CONSUMER BEHAVIOUR IN TOURISM CONTEXTS: THE CASE OF MADEIRA. ENLIGHTENING TOURISM. A PATHMAKING JOURNAL, 9(1), 38-62. doi:http://dx.doi.org/10.33776/et.v9i1.3597 
Sousa, B. M. (2016). A dinâmica diferenciadora eo processo de criação na gestão de destinos turísticos. Revista Brasileira de Pesquisa em Turismo, 10(1), 3-17.

Sousa, B. M., \& Vieira, C. B. (2018). Um Estudo Sobre a Afetividade Aplicada ao Fenómeno do Futebol: Abordagem na Ótica dos Consumidores. PODIUM Sport, Leisure and Tourism Review, 7(2), 293-312.

Sousa, B., \& Simões, C. (2010). Comportamento e perfil do consumidor de turismo de nichos. Tékhne-Revista de Estudos Politécnicos, (14), 137-146.

Tribe, J. (2003). Economia do Lazer e do Turismo. $2^{a}$ Edição. São Paulo: Manole. Trustworthiness of naturalistic inquiries.

UNWTO (2001), Tendencias de los mercados turisticos: Panorama Mundial y Actualidad del Turismo. Madrid.

Veiga, L., \& Gondim, S. M. G. (2001). A utilização de métodos qualitativos na ciência política e no marketing político. Opinião Pública, 7(1), 1-15.

Wahyuni, D. (2012). The research design maze: Understanding paradigms, cases, methods and methodologies.

Warnecke H. (1993). The Fractal Company. A Revolution in Corporate Culture. Springer-Verlag. 